\title{
Commitment of Directorate General of Taxes To Build Public Trust in The Efforts to Achieve Target Tax Revenue
}

\author{
Ida I Dewa Ayu Manik Sastri ${ }^{*}$, Ni Putu Pertamawati ${ }^{2}$ and Luh Kade Datrini ${ }^{3}$ \\ Universitas Warmadewa, Denpasar-Bali, Indonesia \\ \{maniksastri@gmail.com¹,pertama_483@yahoo.co.id ${ }^{2}$, datriniluhkade@yahoo.co.id ${ }^{3}$ \}
}

\begin{abstract}
The implementation of governance and national development in Indonesia requires sustainable financing. The state revenue in 2019 amounted to $74.6 \%$ was received from taxes. This gives an indication that the taxation sector has a very crucial role in ensuring the sustainability of the life of the nation of the country, especially in realising a nation that is smart, prosperous, just and peaceful. Data at the Regional Office of the Directorate General of Taxes (Kanwil DJP) Bali shows that the percentage of the best achievement during the current period occurred in 2019, which was $94.35 \%$. However, it is always a challenge for the Bali Regional Office of DJP to achieve the set targets. Various efforts have been made by the DPJ Bali over the past 5 years, started from Tax Amnesty to the draft Omnibus law (RUU Omnibus law). The public is already open to being able to access and watch what is taking place to the management of the state finances, both from the positive and negative sides, so that the DPJ needs to build public confidence that the finance department is able to account for the funds paid by the public through the DJP so that they are channeled according to plan. The method used in this research is interactive qualitative descriptive method. The results showed that DJP personnel must have high integrity, being more flexible in the service process, being always transparant to the public as well as being transparant in reporting the amount of tax revenue.
\end{abstract}

Keywords: public trust; tax revenue target

\section{Introduction}

The Indonesian tax system adheres to a self-assessment system in that the state gives full confidence to taxpayers to register, calculate, consider the expense, pay and report Tax Returns independently. Therefore, the Indonesian people must have sufficient knowledge to be able to realise their tax rights and obligations as an embodiment of their state obligation.

The problem faced by Indonesian Directorate General of Taxes (hereinafter is referred to as DPJ) at current time is the low tax awareness of taxpayers. The data have shown that only $11 \%$ of Indonesians have registered as taxpayers, $5 \%$ have reported tax returns (SPT), and $0.1 \%$ have paid taxes. For that conditions, the state needs a systematic pattern to change people's behavior in order that they are aware of and comply with tax payment rules, one of which is through education and training.

The present study is a continuation of three previous studies, each of which examined the efforts to increase post-tax amnesty tax revenue (2017) which found that there were several 
strategic activities that had to be carried out by the Bali Regional Office of the DJP in an effort to increase post-tax amnesty tax revenue, namely: socialising the taxation, improving DJP services, intensifying tax audits and seeking the participation of other institutions in providing open access to tax data. A research conducted in 2018 on taxpayer compliance tests before and after tax amnesty found that taxpayers registered in the Regional Office of the DJP Bali were compliant taxpayers, as evidenced by the absence of differences in tax revenues and the number of taxpayer developments before and after the implementation of tax amnesty. Then, the research launched in 2019 was conducted to reveal how to foster taxpayers not to practice tax avoidance. In the results of the study, it was found that it was not tax avoidance that had caused the target not to be achieved, but the lack of public awareness in participating in financing state development. Furthermore, what is the form of collaboration that needs taken by DJP Bali to persuade the taxpayers in oreder that they can sincerely and proudly participate in financing national development through tax payments? Based on this description, a new study entitled "DJP's commitment to building public trust in achieving tax revenue targets" is conducted.

Established on the problem identification described above, the problem examined in this study is formulated into: "What should DJP do in building public trust through motivation, socialisation and increasing community participation in efforts to achieve tax revenue targets?"

The purpose of this research is to assist the government, especially the Kanwil DJP Bali in making policies to invite the public to participate voluntarily in an effort to achieve the state revenue from the tax sector. The benefits of this research are increasing state revenue through taxes.

\section{Literature Review}

\subsection{Tax Awareness Program}

Tax Awareness Program is a program launched by the Directorate General of Taxes in collaboration with stakeholders in the education sector to instill tax awareness by integrating the value of the tax awareness in the national education system through curriculum and learning. The aim of this program is to foster a tax awareness culture from an early age, as part of an effort to build the future of Indonesian taxation and to create the next generation of the nation with the character of defending the country and loving the country through awareness of carrying out good tax obligations properly. Tax awareness should be a national issue that needs to be raised in the learning and teaching to the younger generations. This tax awareness education will indeed take quite a long time. However, it will be useful to organise Indonesian civilisation in the future. Therefore, the tax awareness program requires considerable attention from stakeholders. The state is not only preparing for future generations who are tax conscious and compliant, but also entrusting its own future to future generations.

\subsection{Government policy}

In connection with increasing the taxpayer compliance in state financing, several policies having been implemented are: holding a tax gathering in the form of inviting large taxpayers to gather and eat together in the hope of arousing them. The Tax Awareness Institution Program has also begun to run, in which, DJP considers that taxation education should be started early, from those who are still in school. In all General Subject curricula, tax awareness 
content is included. Every time they make an assignment, lecturers in general subjects such as religion, Pancasila, citizenship and Indonesian must make assignments related to efforts to make taxpayers aware. The assignment must be able to inspire students to make themselves aware of their obligations as citizens.

\subsection{Taxpayer Compliance}

Compliance to meet tax obligations on a voluntary basis is the backbone of the selfassessment system in that taxpayers are responsible for determining their own tax obligations and then accurately and on time pay and report the tax. According to the Decree of the Ministry of Finance of the Republic of Indonesia Number 544/KMK.04/2000 concerning Criteria for Taxpayers whose preliminary refund of tax overpayment is given is a taxpayer who meets the following criteria:

Submit Annual Tax Returns for the past 2 (two) years on time

Does not have tax arrears on all types of taxes for all types of taxes unless the concerned taxpayer has obtained permission to pay taxes or postpone tax payments.

Never been sentenced for committing a criminal offense in the field of taxation within the last 10 (ten) years.

In the case of financial reporting being audited by the Public Accountant or the Financial and Development Supervisory Agency, the implementation must be done with an unqualified opinion or with a qualified opinion as long as the exception does not affect taxable profit and loss.

\section{Method}

Research Place and Object

This research was conducted in the area of the Regional Office of the Directorate General of Taxes (Kanwil DJP) Bali with the object of being the commitment of the DJP Bali to build public trust in an effort to increase tax revenue.

The sample of this research consists of informants, who were the people who provided their opinions and thoughts in solving problems on how to build public trust in achieving tax revenue targets. Samples were taken according to the following criteria:

hold the expertise or qualification in the case being discussed

had practical experience and focus on something problem

were personally involved in the focus of the problem

were an authority figure on the case being discussed

were ordinary people who did not know anything about the problem, but also felt the real problem.

The research data were collected using a questionnaire given to the tax authorities as tax officials who had the authority in implementing state revenue, entrepreneurs as taxpayers, tax consultants as mediators between DJP and taxpayers and lecturers as parties who provided tax education to prospective taxpayers.

Data analysis technique

The research data were analyzed using an interactive qualitative descriptive technique, with 3 stages of analysis, namely:

1. Data collection through interviews and a documentation study

2. Data reduction 
3. Interpretation and conclusion drawing.

\section{Results And Discussion}

DJP is an extension of the state's hand in the effort to obtain state revenue to the maximum extent possible for the prosperity of the people evenly throughout the country. DJP's job is intensively tough but it must be supported by personals with high integrity. In developing countries it is still difficult to build public awareness to share income with the country where it is sheltering, but based on the law, it is not only the right to get the comfort that is demanded, the obligation must also be carried out.

In the results of interviews with respondents, several factors causing taxpayers to lack confidence in the DJP were found, including:

Lack of public trust in the management of tax payments; taxpayers are not sure that their tax payments will be managed properly, so taxpayers think that there is no point in paying large amounts of taxes if they are used for an inappropriate target. They think that the existing money is better used for the welfare of company employees.

There are still unscrupulous DJP employees who lack integrity, such as abusing their authority in the hope of benefiting from certain rewards from taxpayers.

There is transparant coverage of corruption crimes committed by DJP employees.

In the results of the Focus Group Discussion (FGD) that had been carried out, it was found that in order to build the image of the DJP so that people would believe and be willing to pay taxes voluntarily, there are several things that must be done, including:

a) Providing excellent, polite and friendly service to taxpayers.

b) Disseminating tax benefits for national development.

c) Promoting tax reform and various internal reforms that have been carried out by DJP.

d) Establishing Integrity Zones and Corruption-Free Areas in DJP work units.

e) Publishing complaint channels that can be used by the public to report DJP services that do not comply with the provisions.

f) Conducting socialisation in the form of webinars related to the latest tax regulations, so as to open up more insight and perspective of taxpayers on taxation policies in Indonesia.

g) Increasing the number of Account Representatives so that taxpayers can be better served and educated.

\section{Conclusion}

Building upon the description in the previous sections, the conclusion of the research is that some of the causes of taxpayer distrust are:

There is news about criminal acts of corruption committed by DJP employees.Misuse of authority by DJP employees who cornered taxpayers resulting in apprehensiveness in the taxpayers.

Services at the Tax Office (KPP) prioritise procedures set by superiors, not the ease with which taxpayers must accept. 


\section{References}

[1]. Halim, I. R. Bawono and A. Dara, "Perpajakan. Konsep aplikasi, Contoh dan Studi Kasus," Salemba Empat: Jakarta, 2016

[2]. Nugroho and K. Raharjo, "Pengaruh kesadaran wajib pajak dan kpengetahuan perpajakan terhadap kepatuha wajib pajak," Journal of accounting, 2016

[3]. Ferdinant, "Metode Penelitian Manajemen, Pedoman Penelitian untuk Penulisan Skripsi, Tesis dan Disertasi Ilmu Manajemen," Undip Press, 2013

[4]. Johanes, "Analisa Pengaruh Pemeriksaan Pajak terhadap Wajib Pajak dalam Pelaksanaan Undang-Undang PPN dan PPN BM Pada Kantor Pemeriksaan dan Penyidikan Pajak Medan Satu", 2001

[5]. Illhamsyah, "Pengaruh pengetahuan wajib pajak tentang peraturan perpajakan, kesadaran pajak dan kualitas pelayanan terhadap kepatuhan wajib pajak," Jurnal Mahasiswa perpajakan, 2016

[6]. N. Arisandy, "Pengaruh pemahaman wajib pajak, kesadaran wajib pajak dan sangsi pajak terhadap kepatuhan wajib pajak, Jurnal Ilmiah Ekonomi dan Bisnis, ” Unilak, 2017

[7]. M. Trisnawati and S. Wayan, "Analisis Faktor-Faktor yang Mempengaruhi Kepatuhan Wajib Pajak Membayar Pajak Hotel, Pajak Restoran dan Pajak Hiburan di Kota Denpasar”. E-Jurnal Ekonomi dan Bisni Universitas Udayana, volume 4, nomor 12, 2015

[8]. I. D. A. M. M. Sastri, "Faktor-Faktor yang Berpengaruh terhadap Kepatuhan Wajib Pajak Pada KPP Pratama Denpasar Timur", 2016

[9]. I. D. A. M. M. Sastri, "Upaya peningkatan penerimaan pajak pasca tax amnesty pada kanwil DJP Bali," Jurnal Wicaksana Universitas Warmadewa, 2017

[10]. I. D. A. M. M. Sastri, "Uji kepatuhan wajib pajak sebelum dan setelah dilakukannya tax amnesty pada kanwil DJP Bali," Jurnal Wicaksana Universitas Warmadewa, 2018

[11]. I. D. A. M. M. Sastri, "Pendekatan sosial Kanwil DJP Bali dalam mengurangi Tax Avoidance," Jurnal Wicaksana Universitas Warmadewa, 2019

[12]. M .Anam and R Andini, "Pengaruh kesadaran wajib pajak, pelayanan fiskus dan sangsi pajak terhadap kepatuhan wajib pajak orang pribadi," journal off accounting Unpand, 2018

[13]. Kementrian Keuangan Republik Indonesia I. Kantor Pelayanan Pajak Pratama, "ElemenElemen Penunjang Sistem Informasi Direktorat Jenderal Pajak," 2010

[14]. Kementrian Keuangan Republik Indonesia. Direktorat Jenderal Pajak. Direktorat Jenderal Penyuluhan Pelayanan dan Humas, "Undang-Undang Perpajakan. Susunan Dalam Satu Naskah," 2011

[15]. Republik Indonesia. Keputusan Menteri Keuangan Nomor 192/PMK.03/2007 Tentang Kepatuhan Wajib Pajak

[16]. Republik Indonesia. UU No. 6 Tahun 1983 tentangketentuanUmumdan Tata Cara Perpajakansebagaimanatelahdiubahdengan UU No. 16 Tahun 2009 (UU KUP)

[17]. Republik Indonesia. UU No 16 Tahun 2016 Tentang Pengampunan Pajak (Tax Amnesty) 